\begin{tabular}{lr} 
Kastamonu Education Journal & Başvuru Tarihi/Received: 15.04 .2019 \\
Mart 2020 Cilt:28 Sayı:2 & Kabul Tarihi/Accepted: 11.09 .2019 \\
kefdergi.kastamonu.edu.tr & DOI: $10.24106 /$ kefdergi.697203 \\
\hline
\end{tabular}

\title{
Okul Öncesi Dönemdeki Çocukların Problem Temelli Görevlerle Geometrik Şekil Oluşturma Stratejilerinin İncelenmesi
}

\section{Investigating Preschool Age Children's Strategies of Creating Geometrical Shapes in Problem-Based Tasks}

\author{
Halil Ibrahim KORKMAZ ${ }^{1}$, Birol TEKIN²
}

\section{Öz}

Bu araştırmanın amacı, problem temelli görevlerle okul öncesi dönemdeki çocukların şekil (çember, daire, kare, dikdörtgen) oluşturma stratejilerinin incelenmesidir. Araştırma Betimsel Yönteme uygun olarak yürütülmüştür. Araştırmaya, yaşları 54 ile 71 ay aralığında değişen ve Uygun Örneklem Yönteminden yararlanılarak belirlenen toplam 25 çocuk katılmıştır. Çocukların tüm şekilleri tanıma, ayırt etme ve isimlendirme konusunda yetkin olup olmadıklarının belirlenebilmesi amacıyla araştırmacılar tarafından geliştirilen Temel Geometrik Şekilleri Tanıma Envanteri kullanılmıştır. Envanter uygulaması sonucunda tüm şekilleri doğru bir şekilde tanıyan, ayırt eden ve isimlendiren, yaşları 58 ila 71 ay arasında değişen 18 çocukla çalışmalara devam edilmiştir. Çocuklara şekil oluşturmaları için çeşitli materyaller (bir tel, boş bir A4 kağıt, eşit uzunluklardaki iki kağıt şerit ve kare şeklinde bir not kağıdı) sunulmuştur. Sonrasında çocukların şekillerin oluşturulabilmesine yönelik fikirlerinin ve şekil oluşturma stratejilerinin belirlenmesi açısından araştırmacılar tarafından geliştirilen yarı yapılandııımış görüşme formu kullanılmıştır. Elde edilen yazılı verilerin ve çocukların oluşturdukları şekillerin incelenebilmesi açısından Betimsel Analiz Yönteminden yararlanılmıştır. Çocukların cevapları farklı kategoriler altında toplanmıştır. Araştırmanın sonuçlarına göre çocuklar, geometrik şekillerin oluşturulması yönünde çeşitli stratejiler geliştirmekle beraber cesaretlendirildiklerinde daha çok stratejiler geliştirmektedirler. Araştırmanın bulguları doğrultusunda problem temelli görevlerin erken geometri eğitiminde etkili birer öğretim yöntemi olarak kullanılabileceği ve problem temelli öğrenmenin bu yönde geliştirilecek etkinliklerde veya eğitim araştırmalarında kullanılabileceği yönünde önerilerde bulunulmuştur.

Anahtar Kelimeler: Okul öncesi matematik eğitimi, geometrik şekiller, şekil oluşturma, strateji, problem temelli görevler

\section{Abstract}

Aim of this study was to investigate preschool children's strategies of creating shapes (circle, round, square, rectangle) in problem-based tasks. This study was conducted according to Case Study Method. 25 children aged between 54 and 71 months, participated this study. Participants were selected according to Convenience Sampling method. An Inventory of Recognizing Basic Geometrical Shapes which was developed by researchers was used to determine if children are capable to recognize, distinguish and name all the relevant shapes, to investigate children's strategies of creating shapes. Following the implementation of inventory, 18 children (aged between 58 and 71 months) who were capable to recognize, distinguish and name all relevant shapes, were decided to continue to study with. Children were offered different kinds of materials (a wire, a blank paper sized A4, two equal length strip shaped papers and a square shaped notepaper) for them to create shapes. Semi-structured interview questions developed by researchers, were used both to determine children's thoughts about possibilities of creating shapes by using relevant materials, and to investigate children's strategies of creating shapes. Descriptive Analysis Method was used to analyze written records and shapes created by children. Children's responses discussed under different categories. According to the results of this study, children develop different strategies of creating shapes in problem-based tasks, but more when they were encouraged. Problem-based tasks should be used as teaching methods in early geometry education, should be used in educational activities or researches.

Keywords: Preschool mathematics education, geometrical shapes, creating shapes, strategy, problem-based tasks. 


\section{Extended Abstract}

Introduction: Early mathematics education is considered as an important learning field because of mathematics being associated with many other disciplines, such as science, economy, politics. And mathematical knowledge also leads to scientific, economic and political power (Clements \& Sarama, 2009). Children develop their firs mathematical understandings and conceptions by the help of their own experiences. They enjoy doing mathematics, discovering and implementing mathematical relations (QSA, 2006). Children's early mathematical experiences, understandings of mathematics and mathematical relations and their prior knowledge on mathematical concepts are very important as predictor of children's future academic success on mathematics (NCTM, 2013; Verdine et al., 2017). In this respect, children's early mathematical experiences are marvelous learning opportunities (Erdoğan \& Baran, 2003).

Children begin to develop geometrical understanding since they open their eyes to the world (Doverborg \& PramlingSamuelsson, 2001). They bring many of mathematical understandings and conceptions into formal teaching-learning environments, even if they are limited or inadequate (Alisinanoğlu et al., 2013; Altun \& Kırcal, 1999; Aslan, 2004; Chiang, 2013; Clements \& Battista, 1992; Clements et al., 1999; Clements \& Sarama, 2000; Hannibal, 1999; Gal \& Linchevski, 2010; Maier \& Benz, 2012; Satlow \& Newcombe, 1998). Children also develop some geometrical strategies in early years, in the context of geometrical concepts and relations (Elia \& Gagatsis, 2003; Gagatsis et al., 2006). As important as children's early experiences, early childhood educators should be aware of children's prior knowledge and they should find out children's mathematical understandings. Thus, early childhood educators will be capable to offer effective mathematics education and be sensitive against individual differences (QSA, 2006).

According to Sabean \& Bavaria (2005) implementing problem-based activities is one of the most appropriate ways of effective early geometry education, for educators to use children's prior knowledge and understandings as teaching-learning opportunity (The Alliance Education, 2016). Problem-based learning approach requires children to be active learners by using their prior knowledge, and to cooperate with their peers. Thus, children both use and develop their self-regulation, selfdetermination, self-control skills (Başer \& Vatansever, 2018). And, problem-based learning also ensures learners develop alternative thinking skills and strategies (Öksüz \& Uça, 2011). According to Cantürk-Günhan (2006) problem-based learning influences children's geometrical thinking skills and academic success.

In this study, children's geometrical strategies in problem-based tasks were aimed to investigate. Children's strategies in problem-based tasks would be used as effective assessment tool for finding children's geometrical knowledge and understandings, out. And they also would be used as advisor for educators to implement effective early geometry instructions. In this study "what kind of strategies do the children develop in problem-based tasks in context of creating shapes?" main question was posed.

Method: This study was conducted according to Case Study Method. This method ensures us to gather knowledge about facts, in depth and to conduct inquiry processes on different dimensions, based on qualitative data (Türkdoğan, 2014). Children's thoughts and strategies of creating shapes by using different materials in problem-based tasks were analyzed, in this study.

Participants: In this study, preschool age children's strategies of creating shapes were investigated. A total of 25 preschool age children aged between 54 and 71 months (13 girls and 12 boys) participated this study. Convenience Sampling method was used to decide the participants. Convenience sampling method ensures researchers to study with people who are available, close or easy to be studied with (Creswell, 2012).

Data Collection Process: Three different data collection tools were used, in this study. First, Recognizing Geometrical Shapes Inventory was used at the beginning, to be sure that children are capable to recognize and name relevant geometrical shapes. Following the implementation of inventory, 18 children (aged between 58 and 71 months) who were capable to recognize, distinguish and name all relevant shapes were decided to continue to study with. Second, 18 children were offered different kind of materials such as, a wire, a blank paper sized A4, equal length strip shaped paper and a square shaped notepaper for them to create shapes. Third, a semi-structured interview form developed by researchers, were used both to determine children's thoughts about possibilities of creating shapes by using relevant materials, and to investigate children's strategies of creating shapes. Children's responses were only recorded as written records by one on one interviews.

Data Analysis: Fully filled written interview forms were given codes from Ç1 to Ç18. Written forms containing children's responses were analyzed according to Descriptive Analysis method, by two different researchers to obtain interrater reliability. This analysis method ensures us to analyze written, oral or visual data by discussing them under different categories and by using analysis structures (Yıldırım \& Şimşek, 2011). Children's responses about to create the shapes, the reason of to be created or not, were discussed under different categories. A model identification method which was developed by Vasniadou \& Brewer (1992) was used to analyze children's strategies of creating shapes, according to the way and type of creation. Shapes created by children by using different materials were discussed under different models.

Discussion and Results: Findings of this study show us that, most children think, a circle may be created by using a wire, a round may be created by using an A4 sized blank paper, a square may be created by using only two equal length and strip shaped papers, and finally a rectangle may be created by using a square shaped notepaper. We may say that most children are capable to mentally overcome with the problems that are hindering shapes to be created. Besides, children are tended to overcome with

(Kastamonu Eğitim Dergisi, 28(2), 2020) 
the problems more, when they are reminded of the possibilities of creating shapes. It means children may find more solutions to overcome with the problems hindering shapes to be created, when they are encouraged. According to National Council of Teachers of Mathematics (2013) it is so important to encourage children against the difficulties or problems they face in mathematics learning processes.

Materials weren't meeting the requirements of each shapes by their own. Children were expected to manipulate them to create shapes. Most children focused on both properties of geometrical shapes and materials they were offered, by reasoning. Problem-based mathematics learning requires reasoning of mathematical relations (Santi, Utami \& Suwanto, 2017). They expressed some reasons about shapes to be created or not. They thought to adjust the length, shape or size of materials to create expected ones. We may say children are successful at properties of shapes and at creating shapes by manipulating materials to overcome with the problems, as Clements \& Sarama (2000) revealed.

Children were more successful at creating a circle and a round, than creating a square or a rectangle. However, children developed many different strategies to create shapes by manipulating the materials on different ways. We may say that, children are capable to overcome with the problems and to develop various strategies of creating geometrical shapes. Similarly, Elia \& Gagatsis (2003) and Gagatsis et al., (2006) revealed that, children develop various strategies of creating geometrical shapes. In this study, it was seen that, some children used metacognitive strategies. Ghasempour et al. (2013) state that, children use and develop their metacognitive skills in problem-based learning processes.

Recommendations: According to the results of this study, children use and develop various strategies to create shapes, when they encounter with problem-based tasks. Children tend to develop strategies when they are encouraged, even they denied to create a shape, at first. It was also seen that children created shapes by reasoning both the properties of shapes and materials. Thus problem-based activities should be used as teaching ways in early geometry education. Problem-based geometry activities should be used as marvelous learning opportunities. And, problem-based geometry activities should be used for children to manipulate, orientate or create shapes for them to develop geometrical understandings, in depth. Children's strategies in problem-based tasks should be used as effective assessment tool for finding children's geometrical knowledge and understandings, out. And they also would be used as advisor for educators to implement effective early geometry instructions. Finally, problem-based activities or different implementations should be used in educational researches. 


\section{Giriş}

Erken çocukluk döneminde matematik eğitimi, matematiğin çeşitli öğrenme alanları açısından temel bir unsur ol-ması ve uluslararası düzeyde ekonomik, siyasal ve bilimsel açıdan güç sağlayabilecek bir alan olması açısından önemli görülmekte ve hassasiyetle ele alınmaktadır (Clements ve Sarama, 2009). Çocukların erken dönemlerde gelişti-recekleri matematiksel anlayışlar, kazandıkları matematiksel kavram, beceri ve ilişkiler, onların ileriki yıllarda sahip olacakları matematik öğrenme düzeylerini etkileyecek ve temel oluşturacak olan, son derece önemli deneyimlerdir (NCTM [National Council of Teachers of Mathematics], 2013; Verdine, Golinkoff, Hirsh-Pasek ve Newcombe, 2017). Yaşamlarının erken dönemlerinde çocuklar çeşitli deneyimlerle, günlük yaşamlarında bizzat yaparak yaşayarak ma-tematikle ilgili bilgiler öğrenir, severek ve büyük bir keyif alarak matematikle uğraşırlar. Yaşadıkları bu deneyimleri sayesinde belirli bir düzeyde matematiksel anlayışa ve bilgiye sahip olurlar (QSA [Queensland Studies Authority], 2006). Matematik öğrenimi açısından çocukların kendi bireysel çabaları ve deneyimleri ile bazı kazanımlar elde etmiş olmaları çok değerli bir edinim ve son derece önemli bir öğrenme şeklidir (Erdoğan ve Baran, 2003).

Çocukların bireysel öğrenmelerinin yanında onlara sunulacak olan erken matematik eğitiminin daha kaliteli, etkili, verimli ve bireysel farklılıklara karşı duyarlı olabilmesi açısından eğitimcilerin, çocukların sahip oldukları bilgi ve biri-kimden haberdar olmaları, aynı zamanda onları ortaya çıkarmaları gerekir. Ancak bu sayede çocukların sahip olduk-ları bilgiler ve birikimler yeni öğrenme deneyimleri yaşayabilmeleri açısından birer fırsata dönüştürülebilir (QSA, 2006). Erken matematik eğitiminin bir boyutu olarak ele alınabilecek olan erken geometri eğitimi açısından bakıldığında, bebekler doğdukları andan itibaren çevreleri ile yaşadıkları etkileşimler, ebeveyn veya bakım sunan yetişkinlerce ta-şınması ve hareket ettirilmesi ve sonrasında yürümeye başlaması ile kendi çabaları ile dünyayı keşfetme süreçlerinde, (Doverborg ve Pramling-Samuelsson, 2001) içinde bulundukları doğal ve yapılandırılmış çevre ile olan etkileşimlerinde (Charlesworth ve Lind, 2010) çocuklar formal eğitim ortamlarına gelmeden önce geometrik kavramlar ve ilişkiler açı-sından belirli düzeyde bilgi sahibi olmakta ve çeşitli anlayışlar geliştirmektedir (Alisinanoğlu, Kesicioğlu ve Mart, 2013; Altun ve Kırcal, 1999; Aslan, 2004; Chiang, 2013; Clements ve Battista, 1992; Clements, Swaminathan, Hannibal ve Sarama, 1999; Clements ve Sarama, 2000; Hannibal, 1999; Gal ve Linchevski, 2010; Maier ve Benz, 2012; Satlow ve Newcombe, 1998).

Amerikan Ulusal Matematik Öğretmenleri Konseyi'nin belirlediği standartlara göre 0-3 yaş aralı-ğındaki çocukların geometrik şekilleri tanımaları, çevrelerinden geometrik şekillere benzer özelliklerdeki nesneleri göstermeleri; 4-6 yaş aralığındaki çocukların ise geometrik şekilleri tanıyıp çevrelerinden örnekler vermelerine ek olarak şekilleri farkı duruş ve formlarından bağımsız bir şekilde tanımaları, temel şekillerin dışındaki bazı çokgenleri ve bazı 3 boyutlu geometrik formları tanımaları beklenir (NCTM, 2006). Ülkemizde uygulanmakta olan okul öncesi eğitim programında, çocuklardan geometrik şekillerle ilgili olarak daire, çember, üçgen, kare, dikdörtgen, elips, kenar ve köşe kavramlarını kazanmaları ve geometrik şekilleri tanımalarına yönelik kazanım çerçevesinde, kendilerine gösterilen geometrik bir şeklin ismini söylemeleri, özelliklerini söylemeleri ve geometrik şekillere benzer nesneler göstermeleri bek-lenir. Bunun yanında çocukların gelişim ve öğrenme özellikleri doğrultusunda diğer bazı çokgenlerin de kazandırılabi-leceği öngörülür (MEB [Milli Eğitim Bakanlığı], 2013).

Okul öncesi eğitimde yürütülen planlı eğitim öğretim faaliyetleri ile geometri öğrenme alanı açısından çocukların yalnızca geometrik şekilleri ve ilişkileri tanımaları, isimlendirmeleri ve özelliklerini söylemeleri beklenmemelidir. Çocuk-lar geometrik şekilleri oluşturarak, şekillerin özelliklerini ve geometrik ilişkilerini bizzat deneyimlemeli, ortaya koymalı-dır (OME [Ontario Ministry of Education], 2005). Çocuklar zaten bireysel deneyimlerinde geometrik şekillere ait çizim-ler yapmakta, inşa oyunları, bloklar, tangramlar veya etkinlik kartları gibi çeşitli eğitici oyuncaklarla geometrik olu-şumlar ortaya koymakta ve geometrik ilişkileri deneyimlemektedir. Çocuklar bu şekilde geometriye ilişkin bilgi, beceri ve anlayışlarını geliştirmekte, geometriye yönelik temellerini oluşturmaktadırlar (Smith, 2006). Sonuç olarak formel veya formel olmayan yollarla çeşitli deneyimler yaşayan çocuklar, geometrik kavram ve ilişkiler açısından sahip ol-dukları birikimlerinin yanında, bazı sorgulamalar ve akıl yürütme süreçleri sonucunda geometrik kavram ve ilişkiler açısından çeşitli stratejiler de geliştirmektedir (Elia ve Gagatsis, 2003; Gagatsis, Sriraman, Elia ve Modestou, 2006).

Çocukların şekil oluşturma stratejilerinin incelendiği çalışmalardan Maier ve Benz'in (2012) 4-6 yaş aralığındaki çocukların üçgen şeklinin oluşturmalarına yönelik yaptıkları bir çalışmada, çocukların üçgen şeklini farklı büyüklüklerde oluşturma, (Alan) farklı açı özelliklerine sahip üçgenler oluşturma, (Açı Boyutu) üçgen yerine değişik şekiller oluş-turma, (Şekil) sürekli aynı tip şekiller oluşturma, (Aynılık) üçgen şekilleri farklı pozisyon ve yönlerde oluşturma, (Duruş) üçgeni büyüklük, alan, açı özelliği ve duruş açısından çeşitli formlarda oluşturma (Birleşim) ve üçgenin bir 
kenarını eksik oluşturma veya günlük yaşamdan üçgene benzer nesne temsilleri oluşturma (Diğer Örnekler) şeklinde kategorilere yerleştirilen stratejiler geliştirdiğini ortaya koymuştur. Elia ve Gagatsis, (2003) okul öncesi dönem ve ilkokul 1. sınıf öğrencileri ile yaptığı bir araştırmada, okul öncesi dönemdeki çocukların üst yaş grubuna göre, şekilleri oluştururken kenar uzunluğu ve büyüklük gibi özelliklerini değiştirme ve genişletme konusunda daha çok çekingen davrandıklarını, değiştirme açısından ise yalnızca bir ayrıtı üzerinde değişiklik yapma şeklinde stratejiler geliştirdiklerini ortaya koymuş-tur. Gagatsis, Sriraman, Elia ve Modestou (2006) ise 4-8 yaş aralığındaki çocuklarla yaptıkları bir çalışmada, çocukla-rın geometrik şekillere ait çizimlerinde, prototip örneklere göre şekillerin uzunluk ve büyüklük açısından tüm özellikleri-ni büyüten veya küçülten yollar izleyen (T stratejisi); yalnızca bir özelliğini büyüten veya küçülten yollar izleyen ( $\mathrm{O}$ stratejisi) ve hiçbir özelliğini değiştirmeyen yollar izleyen ( $\mathrm{N}$ stratejisi) çeşitli stratejiler geliştirdiklerini ortaya koymuştur. Clements, Wilson ve Sarama (2004) 3-7 yaş aralığındaki çocukların şekilleri birleştirme becerilerini kullanarak yeni şekiller oluşturulması üzerine yaptıkları çalışmada, 3-5 yaş aralığındaki çocukların daha çok deneme yanılma yoluy-la geometrik şekilleri sınırları belirtilen yerlere doğru bir şekilde yerleştirebildikleri, parça şekilleri bitişik dizebilme konu-sunda başarı gösterdikleri (Oluşum Öncesi) 6-7 yaş aralığındaki çocukların ise sınırları belirtilen yerlere doğru şekilleri zaman zaman deneme yanılma yoluyla bulsalar da kenar ve boyut özelliklerini dikkate alarak doğru ve bitişik düzen-de yerleşim yapabildikleri (Resim Oluşturma) ortaya koyulmuştur.

Çocukların geometrik özellikler ve ilişkiler açısından geliştirmiş oldukları stratejiler onlara özgü anlama, anlamlan-dırma, sorgulama, fikir yürütme veya öğrenme yolları olarak değerlendirilebilir. Bu açıdan eğitimcilerin çocukların öğrenme şekil veya stilleri, stratejileri hakkında fikir sahibi olmaları onlara nasıl daha iyi, etkili ve kaliteli bir erken geometri eğitimi sunabilecekleri, onlara nasıl yardımcı olabilecekleri, onlara nasıl iyi bir şekilde destek olabilecekleri konularında yol gösterici, fikir sağlayıcı olacaktır. Erken geometri eğitimi açısından bir eğitimcinin çocuklara nasıl yardımcı olabileceği ve onlara nasıl etkili bir erken geometri eğitimi sunulabileceği konusunda deneyimli ve donanımlı olması gerektiği (Doverborg ve Pramling-Samuelsson, 2001; Erdoğan ve Baran, 2003) düşünüldüğünde çocukların geometrik özellikler ve ilişkiler açısından geliştirdikleri stratejilerin eğitim öğretim faaliyetleri açısından sahip olduğu önem daha iyi anlaşılacaktır.

Sabean ve Bavaria'ya (2005) göre matematik eğitimi açısından, çocukların sahip oldukları bilgi birikimlerinin ve anlayışların, öğrenme süreçlerinde etkili ve verimli bir şekilde ele alınabilmesi açısından problem temelli etkinliklerin sunulması, yürütülebilecek olan en iyi uygulamalardan birisidir (The Alliance Education, 2016). Öğrenenlerin, öğrenme süreçlerinde problem durumları ile yüzleşmeleri, sağlıklı bir öğrenmenin gerçekleşmesi açısından gerekli olan iç moti-vasyonun yüksek düzeyde olmasını sağladığı gibi öğrenilecek unsurlara odaklanmayı da kolaylaştııı. Aynı zamanda problemlerin çözümü açısından bireyler kendi başlarına karar verirler ve yine kendilerine has çözüm yolları veya stra-tejiler geliştirip kullanırlar. Karşılaşılan problemlerin çözümü her zaman için kolay olmayabilir veya istenilen çözüme ulaşılamayabilir. Bu durum ise öğrenme sürecinde sebat gösterme, çözüm için çabalama ve farklı çözüm yolları de-neme ve dolayısıyla da sahip olduğu bilgi birikimini kullanma şansı sunar (Köyceğiz ve Özbey, 2019). Bu açıdan kar-şımıza Problem Temelli Örenme Yaklaşımı çıkmaktadır.

Bu yaklaşımda eğitimciler çocuklara düzeylerine göre kar-maşıklık ve farklı disiplinlerle ilişkiler içerebilen gerçek yaşam problemlerine dayalı görevler sunarlar. Öğrenenler ise probleme yönelik sonuca ulaşmada istediği yol ve stratejiyi uygulamakta serbesttir. Bu yaklaşımdaki asıl amaç öğre-nenlerin bir sorunun yalnız bir çözümü olmayabileceği düşüncesini benimsemeleri, problem çözmede istekli olmaları, edindikleri deneyimleri farklı problemler karşısında kullanabilmeleri ve problem durumlarının içerdiği çoklu disiplinli bağlantıları fark edebilmelerini sağlamaktır (Rashidi, Riabov ve Averhed, 2016). Bu yaklaşım öğrenenlerin öğrenme süreçlerinde aktif bir şekilde yer almalarına, gerekli durumlarda akranları ile iş birliği ve iletişim halinde çalışabilmeleri-ne, öz-belirleme, öz-düzenleme, öz-kontrol ve problem çözme gibi becerilerini işe koşabilmelerine, en önemlisi de sahip oldukları ön bilgileri kullanabilmelerine ve geliştirebilmelerine olanak sağlar (Başer ve Vatansever, 2018; Pawilen, Arre ve Lindo, 2010). Öğrenenler daha çok gerçek yaşamdan izler taşıyan, gerçek yaşamla ilişkilendirilebilen ve esasında sadece tek bir çözüm yolu veya kesin, sabit tek bir cevap beklenmeyen (Hmleo-Silver, 2004) problem durumlarına cevap arayabilmek ve çözüm üretebilmek açısından kendi bilgilerini yapılandıracak düzeyde, problemlere yoğunlaşır, üst düzeyde sorgulama ve çeşitli düşünsel becerilerini geliştirirler (Talib ve Kailani, 2014).

Problem temelli öğrenme yaklaşımı ilk olarak 1950'li yıllarda tıbbi bilimlerde uygulanarak geliştirilen ve sonrasında diğer disiplinlerce benimsenen bir öğrenme yaklaşımıdır (Akt., Çetinkaya, Nur, Ayvaz ve Sümer, 2008). Günümüzde çoğunlukla fen öğretiminde kullanılan (Ayaz, 2015; Balım vd., 2012; Can, Savran-Gencer, Yıldırım ve Bahtiyar, 2016; Çelik, Eroğlu ve Selvi, 2012; Karataş ve Yılmaz, 2016; Konu ve Gül, 2017) bir yaklaşım olmasına rağmen ma-tematik eğitiminde de oldukça etkili bir araç olarak kullanılabilmektedir (Cantürk-Günhan, 2006; Hatısaru, 2015; 
Mulyanto, Gunarhadi ve Indriayu, 2018; O’Brien, Wallach ve Mash-Duncan, 2011; Öksüz ve Uça, 2011; Santi, Utami ve Suwanto, 2017; The Alliance Education, 2016; Usta ve Mirasyedioğlu, 2017). Bu öğrenme yaklaşımı, matematik öğrenme alanında öğrenenlerin alternatif düşünceler ve stratejiler geliştirebilmeleri konusunda katkı sağlayan bir yak-laşımdır (Öksüz ve Uça, 2011). Aynı zamanda bu yaklaşım matematik öğrenme alanında, öğrenenlerin başarısına (Hatısaru, 2015; Mulyanto, Gunarhadi ve Indriayu, 2018; Usta ve Mirasyedioğlu, 2017) matematik öğrenme alanına karşı tutumlarına, (Hatısaru, 2015) matematiksel bazı sorgulamalar yapmalarına (Santi, Utami ve Suwanto, 2017) ve üst bilişsel düşünme becerilerine (Ghasempour, Bakar ve Jahanshahloo, 2013; Talib ve Kailani, 2014) katkılar sunar. Geometri alt öğrenme alanı açısından bakıldığında ise yine olumlu katkılarının olduğu görülmektedir. Bu yaklaşım çocukların geometrik düşünme becerilerine ve geometri öğrenme alanındaki başarılarına katkı sağladığı gibi onların geometri öğrenme alanına yönelik öz-yeterlik inançlarına da katkılar sunar (Cantürk-Günhan, 2006).

$\mathrm{Bu}$ araştırma ile okul öncesi dönemdeki çocukların kendilerine sunulan problem temelli görevler karşısında geomet-rik şekillerin oluşturulmasına yönelik olarak geliştirdikleri stratejilerin incelenmesi amaçlanmıştır. Çocukların sahip oldukları ön bilgiler, geliştirdikleri stratejiler ve yaşadıkları öğrenme deneyimlerinin ortaya çıkarılmasının öğrenme etkinliklerinin planlanması ve şekillendirilmesi açısından sahip olduğu önem (Doverborg ve PramlingSamuelsson, 2001; Erdoğan ve Baran, 2003) ve problem temelli öğrenmenin bu açıdan etkili bir yol olarak kullanılabilirliği (The Alliance Education, 2016) düşünüldüğünde, çocukların geometrik şekillere ilişkin ön bilgi, strateji ve anlayışlarının ortaya çıkarılması, bu özelliklerin amaca hizmet eder bir şekilde öğrenme deneyimlerine dönüştürülmesi açısından eğitimcilere ipucu sağlayacağı ve yol göstereceği düşünülebilir. Araştırmanın amacı doğrultusunda çocukların strateji-lerinin derinlemesine incelenebilmesine yönelik olarak "Okul öncesi dönemdeki çocuklar kendilerine sunulan problem temelli görevler karşısında geometrik şekillerin oluşturulması açısından ne tür stratejiler geliştirmektedirler? ana sorusu-na cevap aranmıştır. Bunun yanında, aşağıdaki alt sorulara cevap aranmıştır.

\section{Okul öncesi dönemdeki çocukların;}

1. Problem temelli görevler karşısında geometrik şekillerin oluşturulabilmesine yönelik düşünceleri nelerdir?

2. Cesaretlendirilmeleri problem temelli görevler karşısında geometrik şekillerin oluşturulabilmesine yönelik düşüncelerini nasıl etkilemektedir?

3. Problem temelli görevler karşısında geometrik şekillerin oluşturulup oluşturulamama nedenleri ile ilgili düşünceleri nelerdir?

\section{Yöntem}

Bu araştırma Durum Çalışmasına (Case Study) uygun olarak yürütülmüştür. Durum çalışması, araştırmacılara bir durum hakkında detaylı bilgi edinme fırsatı sunar. Bu tür araştırmalarda derinlemesine elde edilen bilgiler daha çok nitel verilere dayalıdır. Verilerin elde edilmesi açısından keşfetmeye, betimlemeye ve açıklamaya yönelik sorular kullanılır (Türkdoğan, 2014). Bu araştırmada çocukların probleme dayalı olarak sunulan durumlar karşısında geliştirdikleri stratejiler, probleme dayalı olarak sunulan durumlar karşısından şekillerin oluşturulabilme durumlarına yönelik fikirleri, cesaretlendirilmeleri halinde fikirlerinin etkilenme durumları ve şekillerin oluşturulabilme / oluşturulamama durumlarının nedenleri ile ilgili düşünceleri incelenmiştir.

\section{Katılımcılar}

Bu araştırmaya yaşları 54 ile 71 ay arasında değişen ve ülkemizin, Orta Karadeniz Bölgesi'nde yer alan bir ilimizde, devlete bağlı 2 farklı bağımsız anaokuluna devam eden 13 kız ve 12 erkek toplam 25 çocuk katılmıştır. Çalışmaya katılan çocukların devam ettiği kurumların, dolayısıyla da katılımcıların belirlenmesi açısından Uygun Örneklem (Convenience Sampling) yönteminden yararlanılmıştır. Bu yöntem araştırmacılar için pratiklik sağlayan durumlara göre hareket edilebilmesine ve araştırmanın yürütülmesini kolaylaştıracak olan hedef kitle ile çalışılabilmesine olanak sağlar (Creswell, 2012). Bu araştırmada söz konusu kurumların yakınlığı, çalışmaların yürütülebilmesi açısından yönetici, öğretmen ve diğer personellerin olumlu yaklaşımları, kurumların belirlenmesinde etkili olmuştur. İlk etapta ça-lışmaya katılan çocuklara, araştırmacılar tarafından geliştirilen bir envanter uygulanmıştır. Bu envanter ile çocukların çember, daire, kare ve dikdörtgen şekillerinin her birini ayırt edebilme, tanıyabilme ve isimlendirebilme durumları ince-lenmiştir. Envanter uygulaması sonrasında çocuklarda farklı davranılma hissi oluşturmamak adına yine tüm çocuk-larla problem temelli görevler konusunda görüşmeler yapılmış olup, sadece tüm şekiller açısından başarılı olan, ve yaşları 58 ile 71 ay arasında değişen 10 kız ve 8 erkek, toplam 18 çocuğun görüşme sorularına verdikleri cevaplar ve ortaya koydukları stratejiler araştırma kapsamında veri olarak dikkate alınmıştır. 


\section{Veri Toplama Araçları}

Araştırma kapsamında verilerin elde edilebilmesi için araştırmacılar tarafından geliştirilen 3 farklı veri toplama aracı kullanılmıştır. Illk olarak, çocukların çember, daire, kare ve dikdörtgen şekillerini ayırt edebilme, tanıyabilme ve isimlendirebilme durumlarının belirlenebilmesi amacıyla araştırmacılar tarafından, araştırma kapsamında geliştirilen Temel Geometrik Şekilleri Tanıma Envanteri kullanılmıştır. Envanterin geliştirilmesinde ülkemizde uygulanmakta olan Milli Eğitim Bakanlı̆̆ı Temel Eğitim Genel Müdürlüğü Okul Öncesi Eğitim Programı’nda, çocukların kazanmaları beklenen geometrik şekil kavramları kategorisinde yer alan çember, daire, kare ve dikdörtgen kavramları ve bilişsel gelişim alanında yer alan "geometrik şekilleri tanır" kazanımı altında yer alan "gösterilen geometrik şeklin ismini söyler" gös-tergeleri (MEB, 2013) ile araştırmacılar dışından matematik eğitimi alanında uzman 1 akademisyen ve okul öncesi eğitimi alanında uzman 1 akademisyenin uzman görüşleri dikkate alınmıştır. Bu envanter ile her bir şekil, ayrı sayfa-larda çocuklara gösterilir ve çocukların şekillerin isimlerini doğru bir şekilde söylemesi beklenir. Ardından çocuklardan tüm şekillerin karışık ve her bir şekil için yerleri değiştirilmiş bir düzende ismi söylenen şekilleri tek tek göstermeleri bek-lenir. Bu formda çocuklara sunulan toplam 8 görsel ve şekillere yönelik 8 soru bulunmaktadır. Yöneltilen sorular şekil-lerin isimlendirilmesi açısından "Bu şeklin ismini söyler misin?" ve "Bu şekillerin arasından ...... 'yı gösterir misin?" şeklinde sorulardır. Form ile sunulan görseller ve sorular Ek1 ve Ek2'de paylaşılmıştır.

İkinci olarak, tüm şekilleri başarıyla ayırt eden, tanıyan ve isimlendiren çocukların belirlenmesi sonucunda çocukların problem temelli görevlerde şekilleri oluşturabilmeleri açısından, çember şekli için düz bir tel, daire şekli için A4 boyutunda boş bir beyaz kağıt, kare şekli için eşit uzunlukta ve olabildiğince ince kesilmiş 2 adet kağıt şeridi ve dikdörtgen için karesel bölge oluşturan kare şeklinde bir not kağıdı kullanılmıştır. Çember şekli için problem telin kapalı eğri formunda olmayışı, daire şekli için problem A4 kağıdın dairesel bölge yerine dikdörtgensel bölge oluşturması, kare şekli için problem 4 kenarı olan kare için 2 şerit sunuluyor olması, dikdörtgen şekli için problem sunulan not kağıdının karesel bir alana sahip olması şeklinde belirlenmiştir. Bu aracın geliştirilmesinde yine aynı alan uzmanlarından uzman görüşü ve desteği alınmıştır.

Üçüncü ve son olarak ise, çocukların istenilen şekilleri oluşturabilmeleri açısından sunulan her bir materyalle ilgili yarı yapılandırımış görüşme soruları içeren yarı yapılandırılış bir görüşme formu kullanılııştır. Bu formda yer alan sorular "Sence bu ........ 'yı kullanarak bir .......... şekli oluşturulabilir mi? Neden?", "Sen bu .......... 'yı kullanarak bir ............ şekli oluşturabilir misin? Neden? / Nasıl?”. ve "Bu ........... 'yı kullanarak bir ............. şekli oluşturanları gördüm. Sence nasıl yapmışlardır? Sen de denemek ister misin?" şeklindeki sorulardır. Kullanılan görüşme soruları çocuklarla yürütülebilecek Klinik Görüşme'ye uygun olarak hazırlanmıştır. Bu açıdan yarı yapılandırılmış görüşme soruları tercih edilmiştir. Klinik Görüşme; çocukların bir olgu hakkında sahip oldukları bilgi veya düşüncelerinin açığa çıkarılmasında kullanılabilecek uygun bir yöntemdir. Bu yöntem çocukların düşüncelerini yönlendirmeden soruların şeklini, sırasını veya eş anlamlı bazı kelime grupları kullanarak hafifçe değiştirebilmemize izin verir ve böylece çocuk-ların fikirlerini daha doğru ve derinlemesine bir şekilde öğrenebilmemize yardımcı olur (Ginsburg, 1997).

\section{Veri Toplama Süreçleri}

Araştırmanın her aşamasında yürütülen çalışmalar çocuklarla birebir görüşmeler yolu ile gerçekleştirilmiştir. Çocuk-lardan geometrik şekilleri oluşturmaları bekleneceğinden, öncelikle şekilleri ayırt edebilmeleri, tanıyabilmeleri ve isim-lendirebilmeleri gerekir. Bu açıdan çocuklara ilk olarak Temel Geometrik Şekilleri Tanıma Envanteri uygulanmıştır. Bu envanter sırası ile çember, daire, kare ve dikdörtgen şekilleri için oluşturulan görsellerin sunulması ve her şekle yönelik soruların sorulması şeklinde uygulanmıştır. Form uygulaması sonrasında 25 çocuk arasından tüm şekiller açısından başarılı olan ve yaşları 58 ile 71 ay arasında değişen 18 çocuk belirlenmiştir. Özel uygulama hissi oluşturmamak ve diğer çocuklara karşı ayrımcılık yapmamak açısından ikinci etap uygulamaları yine tüm çocuklarla uygulanmıştır. Form uygulaması sonrasında çocuklara çember, daire, kare ve dikdörtgen şekilleri için sırasıyla yumuşak metal bir tel, boş bir A4 kağıdı, 2 adet ince kağıt şeridi ve 1 adet kare şeklinde not kağıdı sunulmuştur. Çocukların, sunulan her bir materyali problem durumlarının paylaşımı öncesinde incelemelerine izin verilmiştir. Sonrasında oluşturulan yarı yapı-landırımış görüşme soruları sorularak çocukların cevapları yazılı olarak kayıt altına alınmıştır. Problem durumları karşısında materyalleri kullanarak oluşturdukları şekiller ise fotoğraflanarak ve çocuklardan izin alınarak araştırmacı-lar tarafından muhafaza edilmiştir.

\section{Verilerin Analizi}

Araştırma kapsamında tüm şekiller açısından başarılı olan 18 çocuktan elde edilen veriler Ç1 ve Ç18 arasında numaralar verilerek numaralandırılmış, kodlayıcı güvenirliğinin elde edilebilmesi açısından iki farklı araştırmacı tarafından Betimsel Analiz yöntemi kullanılarak analiz edilmiştir. Betimsel analiz yöntemi araştırmacıların elde ettiği sözel, yazınsal veya görsel verileri erişilen anlamsal kategoriler ve çözümleme tabloları sayesinde analiz ederek 
özetlediği bir analiz yöntemidir (Yıldırım ve Şimşek, 2011). Bu araştırmada çocukların düşünceleri ve ortaya koydukları strateji-ler betimsel olarak analiz edilmiştir. Çocukların şekilleri oluşturma stratejilerine yönelik kategoriler aynı zamanda birer model olmakla beraber modellerin belirlenmesinde Vasniadou ve Brewer 'in (1992) öne sürdükleri model tanımlama yöntemi kullanılmıştır. Bu yönteme göre çocukların materyalleri kullanarak oluşturdukları şekiller, oluşturma yolu ve şekline göre modellere yerleştirilmiştir. Oluşan modeller ve modellere ait örnekler Ek 3'de gösterilmiştir.

\section{Geçerlik ve Güvenirlik}

Araştırmanın iç geçerliğini etkileyebileceği düşünülen bazı unsurlar karşısında tedbirler alınmıştır. Öncelikle velilerin izni doğrultusunda hareket edilmiş ve çocukların da katılım konusunda gönüllülük göstermeleri beklenmiştir. Araştır-macılar kendilerini tanıtmış, araştırmanın amacı ve uygulama şekli hakkında bilgi vermiştir. Çocuklar kendilerini ra-hat hissedebilecekleri şekilde diledikleri gibi sınıfta, görüşme odası veya bekleme salonu gibi gürültüden ve diğer çocuk-ların etkileme ihtimalinden uzak olan, kurum bünyesindeki yerlerde görüşmeler sürdürülmüştür. Çocukların tedirginlik yaşamamaları açısından görüşmeler yalnızca yazılı olarak kayıt altına alınmış, çocukların ortaya koyduğu oluşumlar yine izinleri doğrultusunda saklanmıştır.

Temel Geometrik Şekilleri Tanıma Envanteri uygulaması ile tüm şekilleri ba-şarılı bir şekilde tanıyan, isimlendiren ve ayırt eden çocuklar belirlenmiş ancak herhangi bir özel uygulama hissi oluş-turmamak adına çalışmaya ilk etapta katılan tüm çocuklarla görüşmeler gerçekleştirilmiştir, yalnızca ilk uygulamada istenilen kriterlere sahip olan çocukların cevapları ve stratejileri analiz aşamasında dikkate alınmıştır. Verilerin elde edilmesi sürecinde çocukların cevaplarını diledikleri an değiştirebilecekleri hatırlatılmış, görüşmeler sonunda verdikleri cevaplar ve ortaya koydukları oluşumlar soruları ile birlikte tekrar hatırlatılarak teyit etmeleri sağ-lanmıştır. Kodlayıcı güvenirliğinin sağlanması açısından araştırmacıların fikir birliğine vardıkları ve fikir ayrılı̆̆ı yaşa-dıkları durum sayıları tespit edilmiş, Miles ve Huberman'ın (1994) geliştirdiği bir formülden yararlanarak kodlayıcı güvenirliği katsayısı ortaya çıkmıştır. Yapılan incelemelerde kodlayıcı güvenirliği katsayısının ,91 olduğu görülmüştür. Bu sonuçlara göre kodlayıcı güvenirliğinin sağlanmış olduğu söylenebilir (Yıldırım ve Şimşek, 2011).

\section{Sınırlılıklar}

Ülkemizde uygulanmakta olan okul öncesi eğitim programında çocukların çember, daire, üçgen, kare, dikdörtgen ve elips şekillerine ve hatta çocukların gelişim özellikleri doğrultusunda diğer bazı çokgenlere ilişkin anlayış geliştirmele-ri, bazı beceri ve kavramları kazanmaları beklenir (MEB, 2013). Bu araştırmada ise çocuklardan çember, daire, kare ve dikdörtgen şekillerine ilişkin oluşumlar meydana getirmeleri beklenmiştir. Üçgen ve elips şekline ilişkin oluşumlar meydana getirmeleri ise istenmemiştir. Elips şeklinin oluşturulmasının çember şeklinin oluşturulmasına benzerlik gös-terdiği için ayırt edici olamayacağı düşüncesiyle, elips şekli çalışmaya dâhil edilmemiştir. Üçgen şekli açısından ise araştırmacılar tarafından ortaya koyulan fikirlerin pratiklikten uzak oluşu, dâhil edilmemesi noktasında belirleyici olmuştur. Bu nedenle üçgen şekli de çalışmaya dâhil edilememiştir. Ayrıca araştırma için sahip olunan sürenin sınırlı olması ve alınan yasal izinin kapsamı açısından çocukların geometrik şekilleri oluşturma açısından sergileyebilecekleri stratejiler uzun süreli gözlemler ile elde edilememiştir.

\section{Bulgular}

Araştırma ile ortaya çıkan bulgular, çocukların görüşleri açısından sunulan materyaller kullanılarak şekillerin oluşturulabilme durumları ve oluşturulma-oluşturulamama nedenleri, destek ve cesaretlendirme sonrası çocukların düşüncelerinde meydana gelen değişiklikler ve çocuklar tarafından ortaya koyulan şekil oluşturma stratejileri açısından ayrı başlıklar altında ele alınmış ve çeşitli yorumlar getirilmiştir.

\section{Şekillerin Oluşturulabilme Durumlarına iliş̧kin Bulgular}

Çocuklara her bir şekil için farklı materyaller ayrı ayrı sunulmuştur. Çocukların materyalleri incelemeleri sağlandıktan sonra onlara bu materyallerle (tel, A4 kağıt, 2 adet kağıt şerit ve kare şeklinde not kağıdı) şekillerin (çember, daire, kare ve dikdörtgen) oluşturulup oluşturulamayacağı sorulmuştur. Çocukların ilk cevapları dikkate alınmıştır. Çocukların şekillerin oluşturulup oluşturulamayacağına yönelik görüşleri Tablo 1'de sunulmuştur. 
Tablo 1. Şekillerin Oluşturulabilme Durumlarına iliş̧i Bulgular

\begin{tabular}{llll}
\hline Şekil & Oluşturulabilme Durumu & $\boldsymbol{f}$ & $\mathbf{\%}$ \\
\hline \multirow{3}{*}{ Çember } & Oluşturulabilir & 13 & 72,22 \\
& Oluşturulamaz & 5 & 27,77 \\
Daire & Toplam & 18 & $\mathbf{1 0 0}$ \\
& Oluşturulabilir & 72,22 \\
& Oluşturulamaz & 13 & 27,77 \\
Kare & Toplam & 5 & 100 \\
& Oluşturulabilir & 18 & 50,00 \\
& Oluşturulamaz & 9 & 50,00 \\
Dikdörtgen & Toplam & 9 & 100 \\
& Oluşturulabilir & 18 & 72,22 \\
& Oluşturulamaz & 13 & 27,77 \\
\hline
\end{tabular}

Tablo 1 incelendiğinde, çocukların çember, daire ve dikdörtgen şekilleri açısından eşit oranda ve çoğunlukla $(\% 72,22)$ sunulan materyaller kullanılarak söz konusu şekillerin oluşturulabileceği yönünde fikir belirttikleri görülür. Bunun yanında kare şekli açısından ise sunulan materyallerle şeklin oluşturulabileceği veya oluşturulamayacağı yönündeki görüşlerin eşit oranda $(\% 50,00)$ dağıldığı görülür. Genel olarak bakıldığında ise çocukların büyük bir bölümünün problem durumları karşısında geometrik şekillerin oluşturulabileceğini düşündüğünü görebiliriz.

\section{Şekillerin Oluşturulabilme veya Oluşturulamama Nedenlerine ilişkin Bulgular}

Çocuklar kendilerine sunulan materyallerle söz konusu şekillerin oluşturulup oluşturulamayacağı yönünde fikir be-lirtmiştir. Bu düşüncelerinin nedenleri sorulduğunda her bir şekil açısından farklı kategoriler oluşturacak cevaplar alın-mıştır. Çocuklara göre şekillerin oluşturulabilme nedenlerine ilişkin kategoriler ve dağılımları Tablo 2'de sunulmuştur.

Tablo 2. Şekillerin Oluşturulabilme Nedenlerine İlişkin Bulgular

\begin{tabular}{|c|c|c|c|}
\hline Şekil & Oluşturulabilme Nedenleri & $f$ & tf \\
\hline \multirow[t]{2}{*}{ Çember } & Telin Bükülebilir OIması & 13 & \multirow[t]{2}{*}{13} \\
\hline & Kağıda Çizilebilir Olması & 6 & \\
\hline \multirow{4}{*}{ Daire } & Kağıdın Katlanabilir OIması & 4 & \multirow{4}{*}{13} \\
\hline & Kağıdın Kıvrılabilir Olması & 2 & \\
\hline & Kağıdın Kesilebilir OIması & 1 & \\
\hline & Şeritlerin 2'ye Ayrılabilir Olması & 5 & \\
\hline \multirow[t]{3}{*}{ Kare } & Şeritlerin Katlanabilir Olması & 3 & \multirow[t]{3}{*}{9} \\
\hline & Çizimlerle Tamamlanabilmesi & 1 & \\
\hline & Kağıdın 2'ye Ayrılabilir Olması & 6 & \\
\hline \multirow[t]{2}{*}{ Dikdörtgen } & Kağıdın Katlanabilir Olması & 6 & \multirow[t]{2}{*}{13} \\
\hline & Bir Kağıdın Daha Eklenebilir Olması & 1 & \\
\hline
\end{tabular}

Tablo 2 incelendiğinde, düz bir tel ile çember şeklinde bir oluşum meydana getirilebileceğini düşünen çocukların tamamının çember oluşumu için düz bir doğru parçası görünümünde olan telin bükülebilmesi özelliğinden dolayı çember oluşturulabileceği yönünde fikir belirttikleri görülür. Bu açıdan telin düz özellikte olması problemini, bükülebilir olması özelliğinden hareketle ortadan kaldırılabileceğini düşündükleri söylenebilir. Çocukların çember şeklinin oluşturulmasına ilişkin örnek ifadeleri aşağıda paylaşılmıştır.

Ç1 ve Ç17: "Bu teli kullanarak bir çember yapabiliriz. Çünkü teli bükersek çember olur" (Telin Bükülebilir Olması)

A4 boyutlarındaki bir boş kağıt kullanılarak daire şeklinin oluşturulması konusundaki nedenler açısından bakıldığında ise, çocukların 4 farklı kategoride nedenler öne sürdükleri görülür. Çocuklar tarafından en çok dile getirilen nedenler kağıt üzerine bir daire şeklinin çizilebilir olması (6) ve kağıdın katlanabilir özelliğinden yararlanarak bir daireye dönüştürülebileceği (4) ön plana çıkmaktadır. Diğer yandan çocukların, kağıdın kıvrılabilir olması özelliğinden (2) ve kesilerek bir daire elde edilebilmesi (1) özelliğinden dolayı daire şeklinin oluşturulabileceğini düşündükleri görülür. Çocuklara tek başına sunulan bir A4 kağıdın üzerine bir dairenin çizilmesi, kağıdın katlanarak daireye dönüştürülmesi, rulo şeklinde kıvırıp düz zemine dikey yerleştirilmek suretiyle bir daire taban elde edilebileceği düşüncesi ve makasla kesmek suretiyle bir daire elde edilebileceği düşüncesi ile söz konusu çocukların A4 boyutundaki kağıdın özelliklerinin 
sebep olduğu problemin çeşitli şekillerde aşılabileceğini düşündükleri görülür. Aşağıda daire şeklinin oluşturulmasına yönelik çocuklara ait ifade örnekleri paylaşılmıştır.

Ç5: "Bir kalemimiz olsaydı kağıdın üzerine daire yapabilirdik" (Kağıda Çizilebilir Olması)

Ç13: "Kağıdı böyle top gibi yuvarlayıp üstüne çok bastırırsak daire olur, aynı oyun hamuru gibi" (Kağıdın Katlanabilir Olması)

Ç4: “Kağıdı kıvırıp böyle yuvarlak yaparsak yanlarında daire olur” (Kağıdın Kıvrılabilir Olması)

Ç2: "Makasla keseriz ki, o zaman dairemiz olur" (Kağıdın Kesilebilir Olması)

Çocukların kare şeklinin oluşturulabilmesi yönünde 3 farklı kategorilerde nedenler öne sürdükleri görülür. Çocukların en çok, şeritlerin ikişer eş parçaya ayrılabileceğinden dolayı kare oluşturulabileceğini, (5) şeritlerin orta noktalarından katlanarak kare oluşturulabileceğini, (3) ve 2 şeride ek olarak yapılacak çizimlerle kare şeklinin oluşturulabileceğini (1) düşündükleri görülür. Çocukların kare şekli oluşturulması için eksik olan 2 kenar problemini çözebildikleri söylenebilir. Ancak kare şeklinin oluşturulması açısından diğer şekillere göre daha az sayıda çocuğun strateji geliştirebildiği görülür. Çocukların kare şeklinin oluşturulmasına yönelik örnek ifadeleri aşağıda paylaşılmıştır.

Ç3: "Bunları kesersek dört parçamı olur. Karenin dört parçası olur" (Şeritlerin 2'ye Ayrılabilir Olması)

Ç15: “Bu kağıtları böyle 2 ye katlarsak karenin sivri yerleri olur, kare yaparız” (Şeritlerin Katlanabilir Olması)

Ç8: "Bunları üst üste koyarız. Sonra da kalemle çizer kare yaparı" (Çizimlerle Tamamlanabilmesi)

Son olarak dikdörtgen şeklinin oluşturulması açısından çocukların en fazla ve eşit sayıda not kağıdının 2 parçaya ayrılabileceğini (6) ve 2'ye katlanabileceğini, (6) fazladan bir not kağıdı kullanarak uç uca eklemek suretiyle bir dikdörtgen oluşturulabileceğini (1) düşündükleri görülür. Böylelikle çocukların dikdörtgen şeklinin oluşumu için kare şeklindeki bir not kağıdının özelliklerinden kaynaklanan problemin üstesinden gelebilecekleri söylenebilir. Çocukların dikdörtgen şeklinin oluşturulmasına ilişkin örnek ifadeleri aşağıda paylaşılmıştır.

Ç3: "Bu kağıdı kesersek zaten dikdörtgen olur" (Kağıdın 2'ye Ayrılabilir Olması)

Ç15: "Karede olduğu gibi bunu da katlarsak dikdörtgen yaparız" (Kağıdın Katlanabilir Olması)

Ç12: "Bi kağıdımız daha olsaydı yanına koyar dikdörtgen yapardık" (Bir Kağıdın Daha Eklenebilir Olması)

Şekillerin oluşturulabilme nedenlerinin yanında, çocuklara göre şekillerin oluşturulamama nedenlerine ilişkin kategoriler ve dağılımları ise Tablo 3'de sunulmuştur.

Tablo 3. Şekillerin Oluşturulamama Nedenlerine iliş̧kin Bulgular

\begin{tabular}{llll}
\hline Şekil & Oluşturulamama Nedenleri & $f$ & tf \\
\hline Çember & Telin Düz Olması & 5 & 5 \\
Daire & Kağıdın Kenarlarının Düz Olması & 3 & 5 \\
\multirow{2}{*}{ Kare } & Kağıdın Dikdörtgen Şeklinde Olması & 2 & 9 \\
\multirow{2}{*}{ Dikdörtgen } & 2 Şerit Parçasının Eksik Olması & 9 & 5 \\
& Not Kağıdının Kare Şeklinde Olması & 4 & 5 \\
\hline
\end{tabular}

Tablo 3 incelendiğinde, bir tel kullanarak çember oluşturulamayacağı yönünde görüş belirten tüm çocukların (5) telin düz bir yapıda olması ve çember gibi kapalı bir eğri olmaması özelliğine takıldıkları görülür. Çocukların çember şeklinin oluşturulamayacağına yönelik örnek ifadeleri aşağıda paylaşılmıştır.

Ç6: "Çember yuvarlak. Bu düz ki" (Telin Düz Olması)

\section{Ç18: "Bundan çember olmaz çünkü çember yuvarlaktır” (Telin Düz Olması)}

A4 boyutunda boş bir kağıt kullanarak daire şeklinin oluşturulamayacağı yönünde fikir belirten çocukların, kağıdın kenarlarının düz bir şekilde oluşuna (3) ve kağıdın dikdörtgen şeklinin özelliklerine benzer özellikler taşıyor olmasına (2) takıldıkları görülür. Çocukların bu yöndeki ifadelerine örnekler aşağıda paylaşılmıştır.

Ç16: “Kağıdın kenarları dümdüz. Bundan daire olmaz ki” (Kağıdın Kenarlarının Düz Olması)

Ç9: “Bu bir dikdörtgen. Bununla daire yapamayız" (Kağıdın Dikdörtgen Şeklinde Olması) 
2 adet kağıt şerit kullanılarak kare şeklinin oluşturulamayacağı yönünde fikir belirten çocukların tamamının (9) kare şeklinin dört kenarının olmasına ve kendilerine yalnızca 2 adet kağıt şerit sunulmasına takıldıkları görülür. Çocuklara ait bu yöndeki örnek ifadeler aşağıda paylaşılmıştır.

Ç14: "Karenin dört kenarı olur. Ama sen bana 2 tane kağıt verdin" (2 Şerit Parçasının Eksik Olması)

Ç7: "Bunlardan kare yapamayız ki. Karenin dört kenarı vardır" (2 Şerit Parçasının Eksik Olması)

Son olarak dikdörtgen şeklinin oluşturulamayacağı yönünde fikir belirten çocukların en çok not kağıdının kare şeklinin özelliklerine benzer özelliklerinin oluşuna (4) ve sonrasında dikdörtgen şeklinin özelliklerini göstermemesine (1) takıldıkları görülür. Kare şeklinin matematiksel açıdan dikdörtgenin özel bir formu olduğu bilgisi özel bir matematiksel bilgidir. Çocukları geometrik şekillerin öğretimi sırasında kare ve dikdörtgen şekillerinin özellikleri ayrı ayrı aktarılmaktadır. Bu açıdan çocukların verdikleri tepkiler doğal karşılanabilir. Çocukların bu yöndeki örnek ifadeleri aşağıda paylaşılmıştır.

Ç16: "Bu bi kare. Bundan dikdörtgen olmaz ki" (Not Kağıdının Kare Şeklinde Olması)

Ç11: "Bu kare. Dikdörtgen gibi değil” (Dikdörtgenin Özelliklerini Göstermemesi)

\section{Şekil Oluşturma Stratejilerine ilişkin Bulgular}

Çocuklara sunulan materyallerin getirdiği problem durumları karşısında verdikleri ilk cevaplar dikkate alındığında şekillerin oluşturulabileceği yönünde fikir belirten çocuklardan, söz konusu şekilleri oluşturmaları istenmiştir. Bunun yanında şekillerin oluşturulamayacağı yönünde fikir belirten çocuklar ise "Bu 'yı kullanarak bir şekli oluşturanları gördüm. Sence nasıl yapmışlardır? Sen de denemek ister misin?" şeklindeki cesaretlendirici bir soru ile farklı düşünmelerinin desteklenmesi sonucunda bazı çocukların fikirlerini değiştirdikleri görülmüştür. Cesaretlendirme durumuna bağıı olarak çocukların belirttikleri fikirler açısından ortaya çıkan değişiklikler Tablo 4'te sunulmuştur.

Tablo 4. Çocukların Fikirlerinin Değişimine i̇lişkin Bulgular

\begin{tabular}{|c|c|c|c|c|c|}
\hline \multirow{2}{*}{ Şekil } & \multirow{2}{*}{ Oluşturulabilme Durumu } & \multicolumn{2}{|c|}{ illk Durum } & \multicolumn{2}{|c|}{ Son Durum } \\
\hline & & $f$ & $\%$ & $f$ & $\%$ \\
\hline \multirow{3}{*}{ Çember } & Oluşturulabilir & 13 & 72,22 & 18 & 100 \\
\hline & Oluşturulamaz & 5 & 27,77 & 0 & 0,00 \\
\hline & Toplam & 18 & 100 & 18 & 100 \\
\hline \multirow{3}{*}{ Daire } & Oluşturulabilir & 13 & 72,22 & 18 & 100 \\
\hline & Oluşturulamaz & 5 & 27,77 & 0 & 0,00 \\
\hline & Toplam & 18 & 100 & 18 & 100 \\
\hline \multirow{3}{*}{ Kare } & Oluşturulabilir & 9 & 50,00 & 14 & 77,77 \\
\hline & Oluşturulamaz & 9 & 50,00 & 4 & 22,22 \\
\hline & Toplam & 18 & 100 & 18 & 100 \\
\hline \multirow{3}{*}{ Dikdörtgen } & Oluşturulabilir & 13 & 72,22 & 15 & 83,33 \\
\hline & Oluşturulamaz & 5 & 27,77 & 3 & 16,66 \\
\hline & Toplam & 18 & 100 & 18 & 100 \\
\hline
\end{tabular}

Tablo 4 incelendiğinde ilk etapta, sunulan materyaller kullanılarak çember ve daire şekillerinin oluşturulamayacağı yönünde fikir belirten çocukların tamamının cesaretlendirme sonucunda şeklin oluşturulabileceğine kanaat getirdikleri ve bu yönde stratejiler uygulanabileceğini düşündükleri görülmüştür. Çember ve daire şeklinin aksine kare ve dikdörtgen şekli açısından ise şekillerin oluşturulabileceği yönündeki fikirde azımsanmayacak bir artışın olmasına karşın çocukların kare ve dikdörtgen şekilleri açısından dikkate değer bölümlerinin $(\% 22,22, \% 16,66)$ şekillerin oluşturulamayacağı yönündeki fikirlerini korudukları görülmektedir. Sonuç olarak tüm çocuklar çember ve daire şeklinin oluşturulması açısından strateji geliştirmişken, kare şekli açısından 4 ve dikdörtgen şekli açısından 3 çocuk şekil oluşturmaya yönelik strateji geliştirememiştir. Çocukların şekillerin oluşturulmasına yönelik olarak ortaya koydukları stratejilere yönelik oluşturulan modeller, çocuklar tarafından oluşturulan ve modellere uygun örnekler ile dağılımları Tablo 5'te sunulmuştur. 
Tablo 5. Çocukların Şekilleri Oluşturma Stratejilerine ilişskin Modeller

\begin{tabular}{llll}
\hline Şekil & Model & $\boldsymbol{f}$ & $\mathbf{\%}$ \\
\hline Çember & Çember Modeli & 18 & 100 \\
& Çizim Modeli & 8 & 44,44 \\
Kaire & Rutlama Modeli & 5 & 27,77 \\
& Kesme Modeli & 3 & 16,66 \\
& Toplam & 2 & 11,11 \\
& Bölme Modeli & $\mathbf{1 8}$ & $\mathbf{1 0 0}$ \\
Kare & Katlama Modeli & 8 & 57,14 \\
& Hayali Çizgi Modeli & 4 & 28,57 \\
& Toplam & 2 & 14,28 \\
\multirow{2}{*}{ Dikdörtgen } & Bölme Modeli & $\mathbf{1 4}$ & $\mathbf{1 0 0}$ \\
& Katlama Modeli & 7 & 46,66 \\
& Hayali Ekleme Modeli & 6 & 40,00 \\
& Toplam & 2 & 13,33 \\
\hline
\end{tabular}

Tablo 5 incelendiğinde tüm çocukların çember şekline ilişkin bir oluşum meydana getirdikleri ve tamamının $(\% 100,00)$ düz ve yumuşak bir yapıda olan metal telin bükülmesi ile bir çember oluşturulabileceğine yönelik strateji (Çember Modeli) geliştirdikleri görülür. Çocukların daire, kare ve dikdörtgen şekilleri açısından birden çok modele uygun stratejiler geliştirdikleri görülmektedir. Daire şekli açısından çocukların en fazla oranda $(\% 44,44)$ bir kalem yardımı ile A4 kağıdı üzerine bir daire çizme stratejisini (Çizim Modeli) kullandıkları, dikkate değer bir bölümünün ise $(\% 27,77)$ kağıdı katlayarak daire şekline benzetmeye çalıştıkları (Katlama Modeli) görülür. Bazı çocukların $(\% 16,66)$ A4 şeklindeki kağıdı rulo yaparak oluşan silindirin taban alanı meydana getirmesi ile daire oluşturulabileceğine yönelik bir strateji (Rulo Modeli) ve yine bazı çocukların (\%11,11) A4 kağıdından daire şeklinde bir parça keserek bir daire oluşturulabileceğine yönelik bir strateji (Kesme Modeli) ortaya koydukları görülür. Kare şekli açısından bakıldığında bir oluşum meydana getiren çocukların çoğunluğunun $(\% 57,14)$ şeritleri ikişer eş parçaya bölmek suretiyle, (Bölme Modeli) dikkate değer bir bölümünün $(\% 28,57)$ şeritleri ortadan ikiye katlayıp köşe oluşturup birleştirmek suretiyle veya tek bir şeridi sürekli olarak ortadan ikiye katlayarak, (Katlama Modeli), azımsanmayacak bir bölümünün ise $(\% 14,28)$ şeritleri paralel bir şekilde yerleştirip kalem yardımıyla aralarına çizgi çizme veya kollarını şeritlerin arasına yerleştirmek suretiyle (Hayali Çizgi Modeli) kare şeklini oluşturdukları görülür. Dikdörtgen şekli açısından bakıldığında ise bir oluşum meydana getiren çocukların en çok $(\% 46,66)$ kare şekline benzeyen not kağıdını ortadan ikiye bölerek 2 farklı dikdörtgen oluşturarak veya oluşan yeni dikdörtgenleri uç uca eklemek suretiyle, (Bölme Modeli) önemli görülebilecek bir bölümünün $(\% 40,00)$ not kağıdını simetri ekseni boyunca ikiye katlayarak bir dikdörtgen oluşturmak suretiyle (Katlama Modeli) ve son olarak da başka bir not kağıdı daha kullanarak veya olduğunu var sayarak uç uca ek-leme suretiyle (Hayali Ekleme Modeli) dikdörtgen şeklini oluşturdukları görülür. Çocukların oluşturdukları şekiller ve ilgili modeller ayrıca Ek3'de sunulmuştur.

\section{Tartışma ve Sonuç}

Araştırmanın sonucunda yaşları 58 ile 71 ay arasında değişen okul öncesi dönemdeki çocukların kendilerine sunulan problem temelli durumlar karşısında, çember, daire ve dikdörtgen şekillerinin oluşturulabileceği yönünde görüş belirttikleri ortaya çıkmıştır. Ancak kare şekli açısından ise diğer şekillere kıyasla şeklin oluşturulabileceği yönünde daha az oranda fikir belirtmişlerdir. Ortaya çıkan bu durumun kare şeklinin daha spesifik özelliklere sahip olmasından veya sunulan materyallerin özelliklerinden kaynaklanmış olabileceği söylenebilir. Bunun yanında Halat ve Yeşil-Dağlı (2016) ise 5-6 yaş aralığındaki çocukların kare şekline ilişkin anlayışlarının incelenmesi yönünde yaptıkları bir çalışmada çocukların kare şekline ilişkin büyük oranda doğru çizimler ortaya koysalar da önemli bir bölümünün $(\% 35,00)$ kare şekline uygun çizimler yapamadıklarını ortaya koymuştur.

Çocukların ilk fikirlerinin alınmasından sonra, kendilerine sunulan problem durumları karşısında şekillerin oluşturulamayacağını düşünen çocukların cesaretlendirilmeleri sonucunda çember ve daire şekilleri için çocukların tamamının, kare ve dikdörtgen şekli açısından ise önemli bir bölümünün şekillerin oluşturulabileceğini düşünmeye başladıkları görülmüştür. Erken matematik eğitimi açısından çocukların karşılaştıkları matematiksel problemler ve zorlayıcı durumlar (Erdoğan ve Baran, 2003) ile anlamakta zorlandıkları matematiksel ilişkiler karşısında (NCTM, 2013) cesaretlendirilmesi önem arz etmektedir. Bu araştırmanın sonucunda ise şekillerin oluşturulamayacağına yönelik ön fikirleri olan çocukların, cesaretlendirilmeleri sonucunda şekillerin oluşturulmasına yönelik çeşitli stratejiler geliştirmiş olmaları bunu desteklemektedir. 
Yine bu araştırmanın sonucunda çocukların kendilerine sunulan problem durumları karşısında, materyallerin çeşitli özelliklerinden yola çıkarak, onları çeşitli şekillerde manipüle ederek, çeşitli dış kaynak veya imkanlarla bütünleştirerek, bazen ise hayali eklemeler yaparak şekillerin oluşturulabileceğine yönelik nedenlerini ortaya koymuşlardır. Bu açıdan çocukların alternatif düşünme şekilleri ortaya koydukları, şekillerin ve sunulan materyallerin özelliklerinden hareketle çeşitli matematiksel sorgulamalar yaptıkları söylenebilir. Problem Temelli Öğrenme yaklaşımının matematiksel ilişkiler açısından alternatif düşünmeye imkan sağlıyor olmasının (Öksüz ve Uça, 2011) ve matematiksel ilişkiler açııından sorgulamalar yapmalarına imkan sağlamasının (Santi, Utami ve Suwanto, 2017) ortaya çıkan bu sonuçları destekler nitelikte olduğu söylenebilir.

Şekillerin oluşturulamaması açısından nedenler incelendiğinde ise yine çocukların söz konusu şekillerin özellikleri ve kendilerine sunulan materyallerin özellikleri üzerinde sorgulamalar yaptıkları ancak genellikle şekillerin veya materyallerin özelliklerine takılarak şekillerin oluşturulamayacağını düşündükleri görülür. Örnek olarak, kendisine sunulan teli kullanarak bir çember oluşturması beklenen Ç6 kodlu çocuğun "Çember yuvarlak. Bu düz ki" ifadesi; kendisine sunulan a4 boyutundaki bir kağıdı kullanarak daire oluşturması beklenen Ç16 kodlu çocuğun "Kağıdın kenarları dümdüz. Bundan daire olmaz ki" ifadesi; kendisine sunulan 2 adet ince kağıt şeritle bir kare oluşturması beklenen Ç14 kodlu çocuğun "Karenin dört kenarı olur. Ama sen bana 2 tane kağıt verdin" ifadesi ve kendisine sunulan kare çevreli bir not kağıdını kullanarak bir dikdörtgen oluşturması beklenen Ç11 kodlu çocuğun "Bu kare. Dikdörtgen gibi değil" ifadesi gösterilebilir. Çocukların problem durumu karşısında geometrik şekillerin oluşturulması açısından alternatif düşünce geliştiremedikleri görülse de Clements ve Sarama'nın (2000) belirttiğinin aksine şekillerin özelliklerine yönelik sınırı anlayışlar göstermedikleri, aksine şekillerin özelliklerini başarılı bir şekilde ifade ederek şekillerin geometrik ilişkilerine takıldıkları ve bu nedenle oluşturulamayacağına yönelik fikir belirttikleri söylenebilir.

Son olarak araştırmanın sonuçlarına göre, çember, daire, kare ve dikdörtgen şekillerinin tümü açısından çocukların problem temelli durumlar oluşturacak nitelikte kendilerine sunulan materyalleri kullanarak Çember Modelinde, Katlama Modelinde, Rulo Modelinde, Kesme Modelinde, Bölme Modelinde, Hayali Çizgi Modelinde ve Hayali Ekleme Modellerinde çeşitli stratejiler geliştirdikleri görülmüştür. Benzer şekilde bazı araştırmacıların çalışmalarında (Clements, Wilson ve Sarama, 2004; Elia ve Gagatsis, 2003; Gagatsis vd., 2006; Maier ve Benz, 2012) çocukların şekilleri oluşturmaları açısından çeşitli stratejiler geliştirdikleri ortaya koyulmuştur. Bu araştırmada 2 çocuğun A4kağıdı kullanarak bir daire yapmaya çalışırken kağıdı taban alanı (daire) az olacak şekilde bir rulo yapması bunun yanında bir çocuğun ise A4 kağıdının kısa kenarlarını bitiştirerek taban alanı (daire) daha fazla olan bir silindir oluşturması, araştırmaya katılan bazı çocukların kare şekli oluşturmak için kendilerine verilen şeritleri 2'şer eş parçaya bölerek küçük birer kare oluşturmaları, bazı çocukların ise şeritleri olduğu gibi kullanarak eksik kalan kenarları hayali çizgiler veya kollarını kullanarak kapatmaları ve bu şekilde daha fazla alana sahip birer kare oluşturmaları, yine bazı çocukların kare şeklindeki not kağıdını ikiye bölerek dikdörtgen oluşturmaları, bazı çocukların ikiye bölünen parçaları uç uca ekleyerek daha fazla alana sahip birer dikdörtgen oluşturmaları ve bazı çocukların ise kare not kağıdının bitişiğine başka bir kare şeklinde not kağıdı koyarak daha da fazla alana sahip dikdörtgen oluşturmaları, Maier ve Benz'in (2012) çalışmalarında belirttikleri farklı alanlara sahip şekiller oluşturma (Alan) stratejisine benzerdir denilebilir. Bunun yanında Elia ve Gagatsis (2003) okul öncesi dönem çocukların geometrik şekillerin özelliklerini değiştirme konusunda çekingen davrandıklarını, değiştirme eğilimi olarak ise yalnızca 1 ayrıtı değiştirme eğiliminde olduklarını ortaya koyarken bu araştırmada çocuklar, kendilerine hazır olarak sunulmuş geometrik şekiller bulunmamasına rağmen, materyallerin özelliklerini çok çeşitli ve bazen çok çeşitli özelliklerini birden değiştirerek farklı formlarda şekiller oluşturmuştur. Yine bu araştırmada çocukların farklı büyüklük, form ve duruşlarda şekiller oluşturmuş olmaları sebebiyle, Gagatsis, Sriraman, Elia ve Modestou'nun (2006) çalışmalarında çocukların ortaya koyduğu belirtilen ve şekillerin tüm özellikleri ile manipüle edildiği T stratejisine uygun stratejiler geliştirdikleri söylenebilir. Son olarak Clements, Wilson ve Sarama (2004) çalışmalarında 5 yaş çocukların deneme yanılma yoluyla, 6-7 yaş aralığındaki çocukların ise geometrik şekillerin kenar, köşe veya büyüklük gibi özelliklerine dikkat ederek şekilleri ait oldukları uygun yerlere yerleştirdiğini ifade etmiştir. Aksine bu araştırmada, 5 yaş çocukların geometrik şekillerin özelliklerine oldukça iyi düzeyde dikkat ettikleri ve hatta bazı durumlarda geometrik şekillerin özelliklerine takıldıkları için problem durumları karşısında şekillerin oluşturulamayacağını ifade ettikleri görülmüştür.

Bu araştırmada şekilleri oluşturmaları yönünde stratejilerini ortaya koyarken bazı çocuklar yalnızca kendilerine sunulan materyallerle yetinmiş, bazıları o materyalleri çeşitli şekillerde dönüştürmüş, bazıları farklı ek materyaller kullanmış bazıları ise hayal güçlerini kullanarak materyalleri zihinlerinde manipüle etmişlerdir. Sonuç olarak kendilerine sunulan ve şekillerin oluşturulması yönünde problem durumları içerek materyallerden yola çıkarak üst bilişsel düşünme becerilerini ortaya koymuşlardır. Buna en iyi örnek olarak Ç4 kodlu çocuğun düz bir A4 kağıdını rulo haline getirip, masanın zeminine dik bir şekilde konumlandırarak tabanında bir daire oluşturduğunu ifade etmesi; Ç10 kodlu çocuğun kendisine sunulan iki ince kağıt şeridini birbirine paralel bir şekilde yerleştirip kolları ile eksik kalan kenarları 
tamamladığını söyleyerek bir kare oluşturduğunu ifade etmesi ve Ç12 kodlu çocuğun kendisine sunulan kare şekline benzeyen not kağıdından bir tane daha olması durumunda dikdörtgen şeklini oluşturabileceğini ifade etmesi buna örnek gösterilebilir. Ghasempour vd. (2013) ile Talib ve Kailani'nin (2014) ortaya koyduğu gibi çocuklar Problem Temelli öğrenme süreçlerinde üst bilişsel becerilerini kullanma ve geliştirme fırsatı bulmaktadırlar.

\section{5. Öneriler}

Bu araştırma ile ortaya çıkan sonuçlar incelendiğinde çocukların şekillerin oluşturulması konusunda problem durumları ile karşılaştırıldıklarında çok çeşitli stratejiler geliştirerek şekil oluşturabildikleri, şekillerin oluşturulabilmesi açısından herhangi bir fikri olmayan çocukların ise cesaretlendirilmeleri sonucu çözüme yönelik stratejiler geliştirebildikleri, çocukların karşılaştıkları problem temelli görevlerde çeşitli matematiksel sorgulamalar yaptıkları ve alternatif düşünceler geliştirdikleri görülmüştür. Bu açıdan uygulamaya dönük olarak, probleme dayalı görevler veya etkinlikler erken geometri eğitimi kapsamında kullanılabilecek bir öğretim yolu olarak tercih edilebilir. Çocukların geometrik şekiller ve özellikleri hakkında sorgulamalar yapabilmeleri, yeni anlayışlar kazanabilmeleri ve ilgili kavramları daha etkili bir şekilde yaparak, yaşayarak kazanabilmeleri açısından problem temelli öğrenme deneyimlerine dönüştürülebilir.

Araştırmaya dönük olarak ise, problem temelli öğrenme şekillerin oluşturulmasının yanında dönüştürülmesi ve manipüle edilmesi ile yürütülecek çeşitli etkinliklerde veya araştırmalarda kullanılabilir. Çocukların temel ve daha karmaşık geometrik şekilleri öğrenme süreçlerinde problem temelli görevlerin etkililiğinin belirlenmesine, çocukların geometrik şekillere ilişkin geliştirdikleri anlayışların, matematiksel ilişkileri anlama, karşılaştırma ve muhakeme etme durumları ile kavramsallaştırma yapılarının belirlenmesine yönelik araştırmalar yürütülebilir. Bunun yanında problem temelli görevler çocukların sahip oldukları yanlış anlayış ve kavram yanılgılarının belirlenmesi ve giderilmesinde birer araç olarak kullanılabilir, bu yönde araştırmalar yürütülebilir. Ayrıca bu araştırmada ele alınmayan geometrik şekillerden üçgen ve elips şekilleri ile okul öncesi dönemdeki çocukların gelişim özelliklerine göre belirlenebilecek diğer bazı çokgenlerin oluşturulması üzerine çalışmalar genişletilebilir. Araştırma uzun soluklu gözlemlerden yararlanılarak çocukların serbest deneyimlerinde ortaya koydukları geometrik stratejilerin incelenmesi veya çeşitli veri toplama araçlarından yararlanılarak geliştirilmesi şekkinde tekrarlanabilir.

\section{Bildirim}

Bu araştırma ile elde edilen verilerin bir kısmı 3-6 Temmuz 2017 tarihleri arasında, Amasya İlinde düzenlenen 15. Uluslararası Geometri Sempozyumu'nda “Pre-School Age Children's Strategies of Composing Two Dimensioned Shapes: In the Context of Creativity" başlıklı sözlü bildiri olarak sunulmuştur.

Araştırmanın planlama, uygulama ve yazım sürecinde, bilimsel, etik ve alıntılama kurallarına uyulmuş olup, elde edilen veriler bilimsel yöntem ve yaklaşım çerçevesinde ele alınmıştır. Bu araştırma başka herhangi bir akademik yayın platformuna değerlendirilmek üzere gönderilmemiştir.

\section{Kaynakça}

Alisinanoğlu, F., Kesicioğlu, O.S. ve Mart, M. (2013). Evaluation of pre-school children's development of geometric thought in the UK and Turkey according to Van Hiele model. International Journal of Education and Research, 1(10), 1-10.

Altun, M. ve Kırcal, H. (1999). 3-7 yaş çocuklarında geometrik düşünmenin gelişimi. Pamukkale Üniversitesi Eğitim Fakültesi Dergisi, 6(6), 71-79.

Aslan, D. (2004). Anaokuluna devam eden 3-6 yaş grubu çocuklarının temel geometrik şekilleri tanımalarının ve geometrik şekilleri ayırt etmede kullandıkları kriterlerin incelenmesi. (Yayınlanmamış Yüksek Lisans Tezi). Çukurova Üniversitesi Sosyal Bilimler Enstitüsü, Adana.

Ayaz, M., F. (2015). Probleme dayalı öğrenme yaklaşımının öğrencilerin fen derslerindeki akademik başarılarına etkisi: bir meta-analiz çalışması. Electronic Turkish Studies, 10(3), 139-160.

Balım, A., G., Deniş-Çeliker, H., Kaçar, S., Evrekli, E., Türkoğuz, S., İnel, D., Özcan, E. ve Ormancı, Ü. (2016). Fen ve teknoloji öğretiminde probleme dayali öğrenme yöntemi içerisinde kavram karikatürleri: bir etkinlik örneği "isinan taneciklerin dansi". Western Anatolia Journal of Educational Science. 3(5), 68-87.

Başer, A. ve Vatansever, K. (2018). Probleme dayalı öğrenme: Tıp ve diş hekimliği eğitiminde bir öğrenme yaklaşımı. Smyrna Tıp Dergisi, 2018 (1), 69-74. 
Can, B., Savran-Gencer, A., Yıldırım, C., ve Bahtiyar, A. (2016). Fen Öğretiminde Probleme Dayalı Öğrenme: 5., 6., 7. ve 8. Sınıf Kazanımlarına Yönelik Senaryo Etkinlikleri. Ankara: Pegem Akadem.

Charlesworth, R. ve Lind, K. K. (2010). Math \& Science for Young Children, Belmont: Wadsworth.

Chiang, N. C. (2013). Influence of global shapes on children's coding of local geometric information in small-scale spaces. Learning and Motivation. 44, 16-30.

Clements, D. H. ve Sarama, J. (2009). Learning and teaching early math: The learning trajectories approach. New York: Routledge.

Clements, D. H., Swaminathan, S., Hannibal, M. A. Z., ve Sarama J. (1999). Young children's concepts of shape. Journal for Research in Mathematics Education. 30(2), 192-212.

Clements, D. H. ve Battista, M. T. (1992). Geometry and spatial reasoning. İçinde Grouws, D. A. (Ed.) Handbook of Research on Mathematics Teaching and Learning. Reston: NCTM.

Clements, D. H ve Sarama, J. (2000). Young children's ideas about geometric shapes. Teaching Children Mathematics. 6(8), 482,488.

Clements, D. H., Wilson, D. C., ve Sarama, J. (2004). Young children's composition of geometric figures: A learning trajectory. Mathematical Thinking and Learning, 6(2), 163-184.

Creswell, J. W. (2012). Planning, conducting, and evaluating quantitative and qualitative research. Boston: Pearson.

Çelik, E., Eroğlu, B. ve Selvi, M. (2012). Fen eğitiminde probleme dayali öğrenme yaklaşiminin öğrencilerin akademik başarisi ile fen ve teknoloji dersine yönelik tutumlarina etkisi. Kastamonu Eğitim Dergisi. 20(1), 187-202.

Çetinkaya, S., Nur, N., Ayvaz, A. ve Sümer, H. (2008). Yeni bir öğrenim modeli probleme dayalı öğrenimde ilk yıl deneyimimiz. Cumhuriyet Üniversitesi Tıp Fakültesi Dergisi, 30(2), 53-57.

Günhan, B. C. (2006). Illköğretim II kademede matematik dersinde probleme dayalı öğrenmenin uygulanabilirliği üzerine bir araştırma (Yayınlanmamış Doktora Tezi), Dokuz Eylül Üniversitesi Eğitim Bilimleri Enstitüsü.

Doverborg, E., ve Samuelsson, I. P. (2001). Children's experience of shape in space. For the Learning of Mathematics, 21(3), 32-38.

Erdoğan, S. ve Baran, G. (2003). Erken çocukluk döneminde matematik. Eğitim ve Bilim. 28(130), 32-40.

Elia, I., ve Gagatsis, A. (2003). Young children's understanding of geometric shapes: The role of geometric models. European Early Childhood Education Research Journal, 11(2), 43-61.

Gal, H., ve Linchevski, L. (2010). To see or not to see: analyzing difficulties in geometry from the perspective of visual perception. Educational Studies in Mathematics, 74(2), 163-183.

Ghasempour, Z., Bakar, N., ve Jahanshahloo, G. R. (2013). Innovation in teaching and learning through problem posing tasks and metacognitive strategies. International Journal of Pedagogical Innovations, 1(1), 57-66.

Gagatsis, A., Sriraman, B., Elia, I. ve Modestou, M. (2006). Exploring young children's geometrical strategies. Nordic Studies in Mathematics Education, 11 (2), 23-50.

Ginsburg, H. (1997). Entering the child's mind: The clinical interview in psychological research and practice. Cambridge University Press.

Halat, E., ve Dağli, Ü. Y. (2016). Preschool students' understanding of a geometric shape, the square. Bolema: Boletim de Educação Matemática, 30(55), 830-848.

Hannibal, M. A. (1999). Young children's developing understanding of geometric shapes. Teaching Children Mathematics. 5(6), 353-357.

Hatısaru, V. (2015). Probleme Dayalı Öğrenme Yönteminin Uygulandığı Matematik Derslerinde Öğrenci Gelişiminin İncelenmesi. Gaziantep University Journal of Social Sciences, 14(2), 459-477.

Hmelo-Silver, C., E. (2004). Problem-based learning: What and how do students learn?. Educational Psychology Review, 16(3), 235-266. 
Karataş, F. Ö. ve Yılmaz, P. (2016). Probleme dayalı senaryoların 9. sınıf öğrencilerinin kimya dersine olan tutumlarına, laboratuvar kaygılarına ve problem çözme algılarına etkisi. Journal of the Turkish Chemical Society Chemical Education, 1(2), 39-66.

Konu, M. ve Gül., Ş. (2017). Biyoloji dersinde yaşam temelli probleme dayali öğretim uygulamalarinin tutum, motivasyon ve problem çözme becerilerine etkisi. Hasan Ali Yücel Eğitim Fakültesi Dergisi, 14-1(27), 127-142.

Köyceğiz, M. ve Özbey, S. (2019). Okul öncesi eğitim kurumlarına devam eden çocukların motivasyon düzeylerinin problem çözme becerileri ve öğretmenlerine ilişkin bazı değişkenler açısından incelenmesi. Folklor/Edebiyat, 25(97-1), 571-610.

Maier, A. S. ve Benz, C. (2012). Development of geometric competencies - Children's conception of geometric shapes in England and Germany. POEM 2012 Conference, Frankfurt, 27-29 February 2012.

MEB (Milli Eğitim Bakanlığı) (2013). Milli eğitim bakanlığı temel eğitim genel müdürlüğü, okul öncesi eğitim program. Ankara: Milli Eğitim Bakanlığı. [Çevrim içi: http://tegm.meb.gov.tr/dosya/okuloncesi/ooproram.pdf. Erişim tarihi: 18 Mart 2015]

Mulyanto, H., Gunarhadi, G., ve Indriayu, M. (2018). The effect of problem based learning model on student mathematics learning outcomes viewed from critical thinking skills. International Journal of Educational Research Review, 3(2), 37-45.

NCTM (National Council of Teachers of Mathematics) (2006). Curriculum focal points for prekindergarten through grade 8 mathematics: A quest for coherence. Reston: NCTM.

NCTM [National Council of Teachers of Mathematics] (2013). Mathematics in Early Childhood Learning: A Position of the National Council of Teachers of Mathematics, Reston: NCTM.

O'Brien, T., C., Wallach, C. ve Mash-Duncan, C. (2011). Problem-based learning in mathematics, The Mathematics Enthusiast. 8(1), 146-160.

OME (Ontario Ministry of Education) (2005). A guide to effective instruction in mathematics kindergarten to grade 3: Geometry and spatial sense. Ontario: Ontario Ministry of Education.

Öksüz, C., ve Uça, S. (2011). Matematik dersinde probleme dayalı öğrenme üzerine bir örnek olay. Adnan Menderes Üniversitesi Eğitim Fakültesi Dergisi, 2(2), 20-29.

Pawilen, G. T., Arre, J. P., ve Lindo, E. F. (2010). Designing an integrated curriculum for preschool. Asia-Pacific Journal of Research in Early Childhood Education, 4, 57-76.

QSA [Queensland Studies Authority] (2006). Early Years Curriculum materials: Developing Early Mathematical Understandings. Brisbane: QSA.

Rashidi, A., Riabov, D. ve Averhed, Y. (2016). Early Learn to Learn Environment. [Çevrim içi: http://www.vrticmatijegupca.zagreb.hr/UserDocsImages/Roadmap-\%20EL2LE.pdf. Erişim tarihi: 04 Eylül 2019]

Santi, M., Utami, R. W. ve Suwanto, F. R. (2017). Problem based learning to improve proportional reasoning of students in mathematics learning. In AIP Conference Proceedings 1868(1), AIP Publishing.

Satlow, E. ve Newcombe N. (1998) When is a triangle not a triangle? Young children's developing concepts of geometric shape. Cognitive Development. 13, 547-559.

Smith, S. S. (2006). Early childhood mathematics. (3rd Edition). Boston: Pearson.

Talib, A., ve Bin-Kailani, I. (2014). Problem based learning in cooperative situation (PBLCS) and its impact on development of personal intelligence. International Journal of Evaluation and Research in Education, 3(4), 236-244.

The Alliance Education (2006). Closing The Achievement Gap: Best Practices In Teaching Mathematics, Charleston: The Alliance Education.

Türkdoğan, A. (2014). Nicel, Nitel Ve Karma Araştirma. İçinde Demir, S. B. (Çev. Edt.). Eğitim Araştırmaları, 29-56.

Usta, N ve, Mirasyedioğlu, Ş. (2017). Problem Tabanlı Öğrenme Yaklaşımı ile Matematik Öğretiminin 7. Sınıf Öğrencilerinin Matematik Başarısına ve Öz-yeterliğine Etkisi. Kastamonu Eğitim Dergisi, 25(6), 2263-2282. 
Vosniadou, S., ve Brewer, W. F. (1992). Mental models of the earth: A study of conceptual change in childhood. Cognitive Psychology, 24(4), 535-585.

Verdine, B. N., Golinkoff, R. M., Hirsh-Pasek, K., ve Newcombe, N. S. (2017). VI. discussion and implications: How early spatial skills predict later spatial and mathematical skills. Monographs of the Society for Research in Child Development, 82(1), 89-109.

Yıldııım, A. ve Şimşek, H. (2011). Sosyal bilimlerde nitel araştırma yöntemleri (8.baskı). Ankara: Seçkin Yayıncılık.

\section{Ek1. Temel Geometrik Şekilleri Tanıma Envanteri (Sayfa 1-4)}

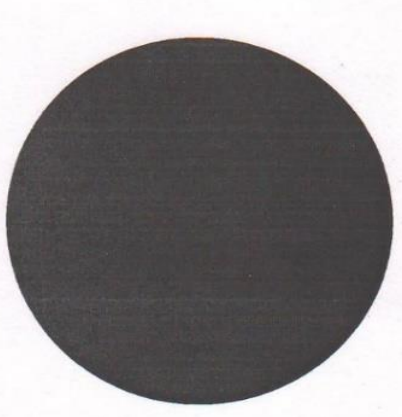

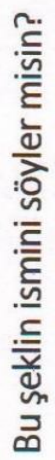

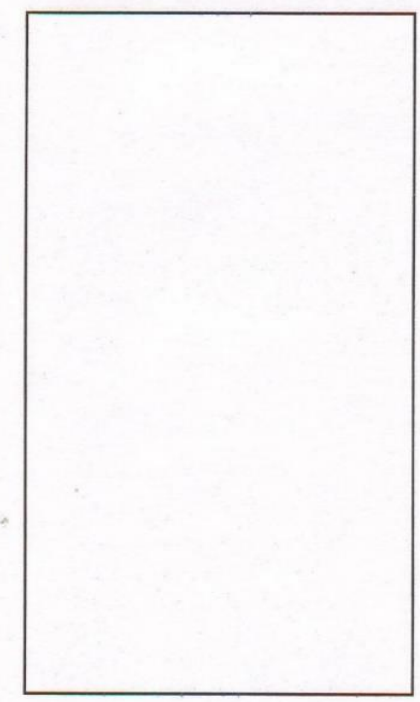

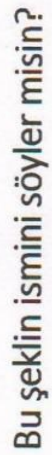
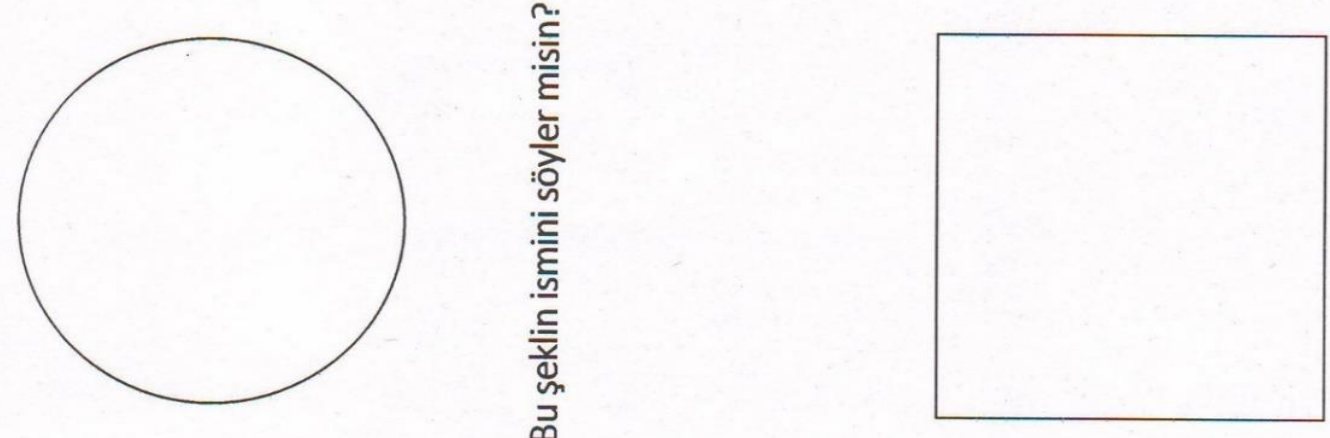
Ek2. Temel Geometrik Şekilleri Tanıma Envanteri (Sayfa 5-8)
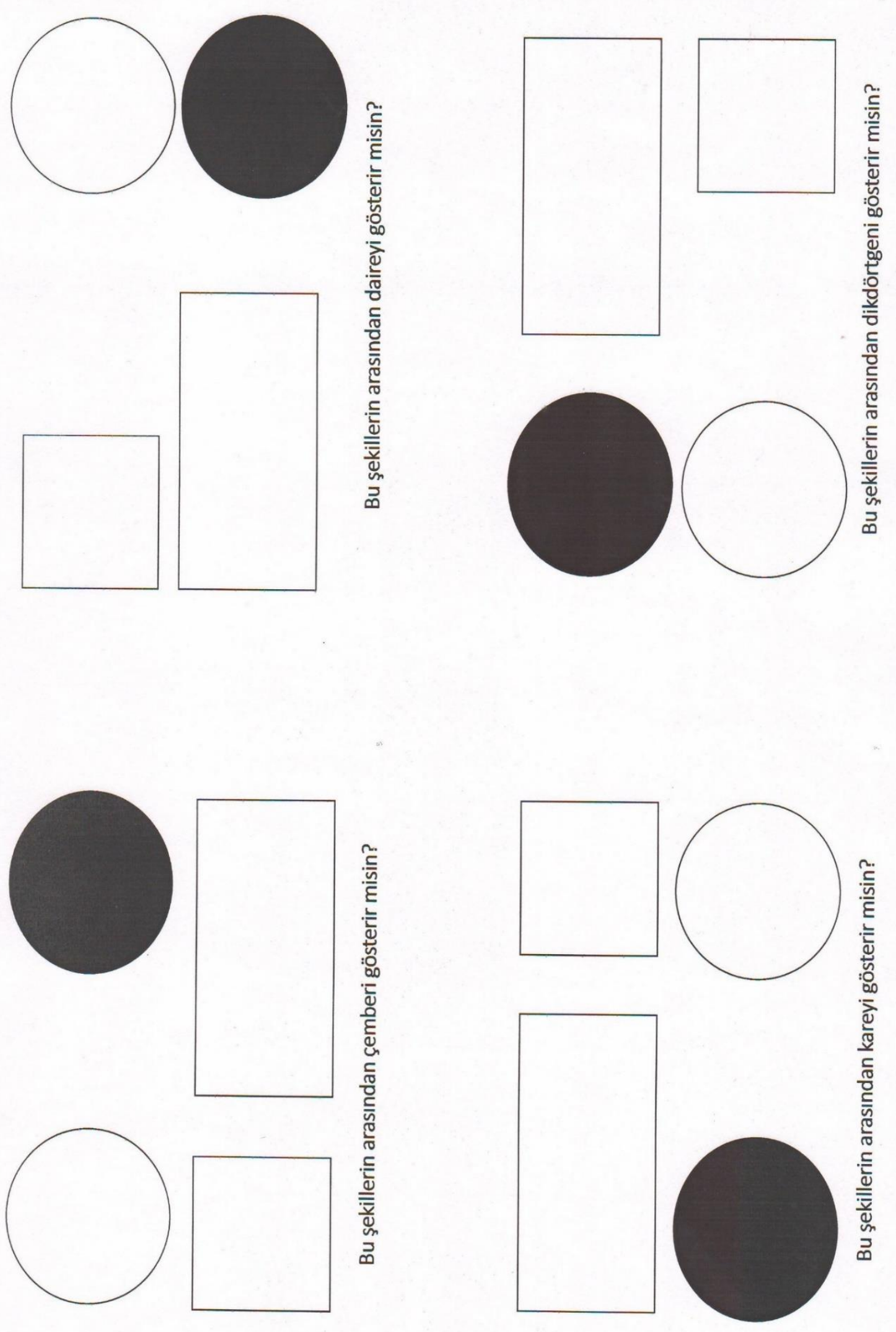
Ek3. Çocukların Şekil Oluşturma Stratejilerine Yönelik Ortaya Çıkan Modeller

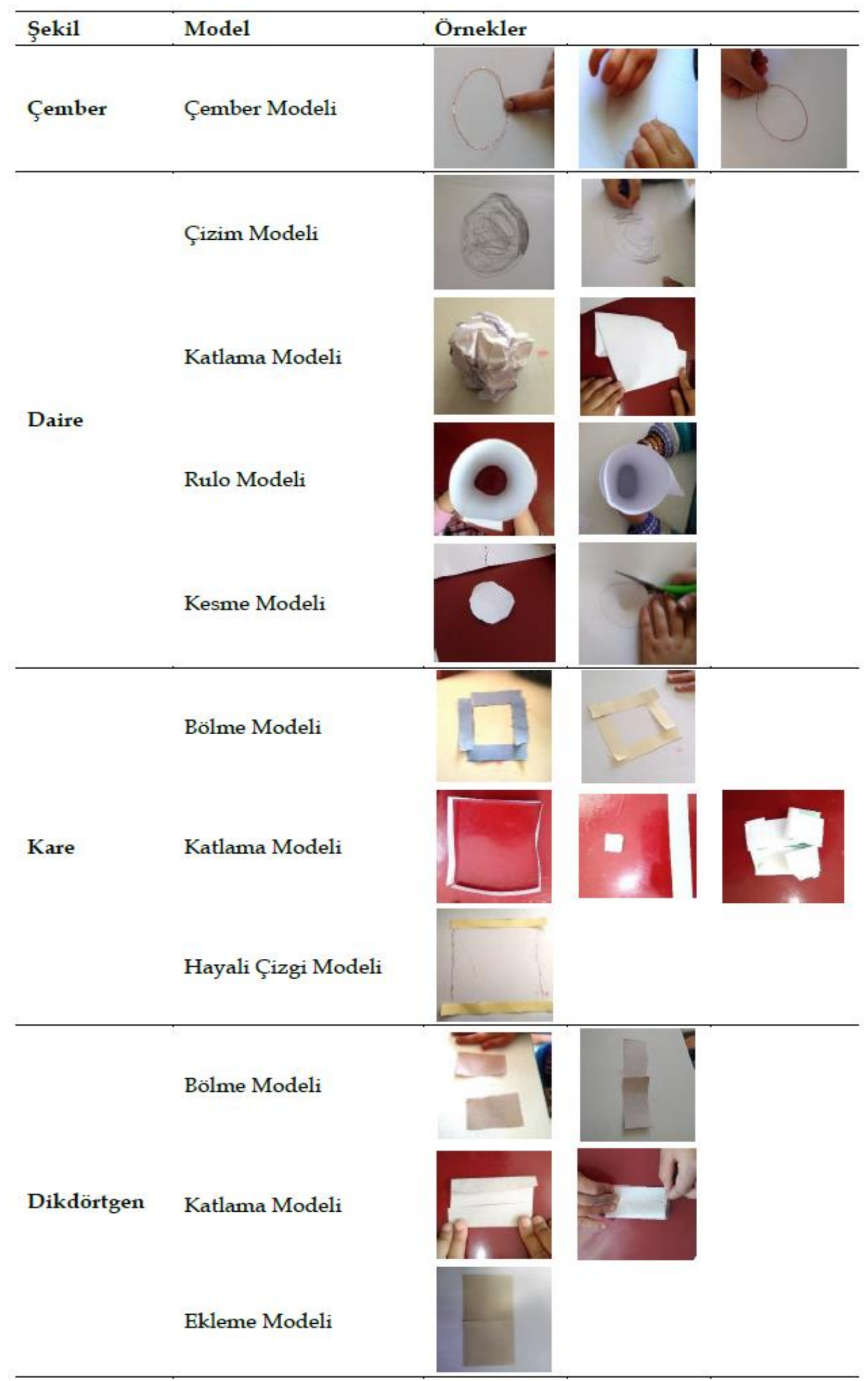

